Jurnal Inkofar * Volume 1 No. 1 Juli 2019 * ISSN: 2615-3645 (Print) / 2581-2920 (Online)

Tersedia secara online di: http://www.politeknikmeta.ac.id/meta/ojs/

\title{
IMPLEMENTASI WAP (WIRELESS APPLICATION PROTOCOL) DAN WEB UNTUK LAYANAN SISTEM INFORMASI NILAI MAHASISWA (Studi Kasus: Politeknik Meta Industri Cikarang)
}

\author{
Manase Sahat H Simarangkir ${ }^{1}$, Adam Puspabhuana ${ }^{2}$ \\ ${ }^{1}$ Teknik Komputer / Program D3 / Politeknik Meta Industri Cikarang/ \\ manasemalo@politeknikmeta.ac.id \\ ${ }^{2}$ Teknik Komputer / Program D3 / Politeknik Meta Industri Cikarang/ adam.bhuana@gmail.com
}

\begin{abstract}
Wireless Application Protocol (WAP) technology is a combination of internet technology and wireless technology that information could be accessed anywhere as long as it is connected to the internet and uses wireless media. The development of technology in various fields encourages the development of information technology in producing information that is useful for supporting decisions in the community, institution or organization. In order to produce effective and efficient decisions, a system is needed that is able to process data into appropriate information. One of the developing technologies is cellular telephone technology. Information could be accessed easily and quickly.by using cellular telephone technology. Recently, at the Cikarang Meta Industrial Polytechnic institution there is no WAP-based information system that process student's grade. WAP based technology is implemented in order to help students or web administrator getting information anywhen and anywhere as long as using their cellular phone. This research uses research method including data collection, library studies, design, programming, testing and system implementation. The programming language used is Wireless Markup Language and PHP with MySQL database support. At the testing and implementation stage, the system could be accessed by web administrator using only the website while information about student's grade could be used using cell phones and websites. The final result of the research is to have an information system, where students could get the student's grade using cellular phones and websites.
\end{abstract}

Keywords: cellular phone, WAP, browser, website, php, mysql

\begin{abstract}
ABSTRAK
Teknologi Wireless Application Protocol (WAP) merupakan penggabungan antara teknologi internet dengan teknologi nirkabel sehingga untuk mengakses informasi bisa dilakukan dimana saja selama terhubung dengan internet dan menggunakan media nirkabel. Perkembangan teknologi diberbagai bidang mendorong berkembangnya teknologi informasi dalam menghasilkan informasi yang berguna untuk pengambilan berbagai keputusan penting baik di masyarakat, institusi atau organisasi. Untuk menghasilkan keputusan yang efektif dan efisien dibutuhkan sistem yang mampu mengolah data menjadi informasi yang tepat guna. Salah satu teknologi yang berkembang adalah teknologi telepon selular. Dengan teknologi telepon selular, informasi bisa diakses dengan mudah dan cepat. Pada institusi Politeknik Meta Industri Cikarang belum adanya sistem informasi pengolahan nilai mahasiswa berbasis WAP. Dengan memanfaatkan teknologi berbasis WAP bertujuan agar informasi nilai mahasiswa dapat diakses oleh mahasiswa atau web admin kapanpun dan dimanapun menggunakan telepon selular. Metode penelitian yang dilakukan meliputi pengumpulan data, studi kepustakaan, perancangan, pemrograman, uji coba dan implementasi sistem. Bahasa pemrograman yang digunakan yaitu Wireless Markup Language serta PHP dengan dukungan basisdata MySQL. Pada tahap pengujian dan implementasi, sistem dapat diakses oleh web admin hanya menggunakan website sedangkan untuk mengakses informasi nilai mahasiswa dapat menggunakan telepon seluler dan website. Hasil akhir penelitian yaitu menghasilkan sistem informasi, dimana mahasiswa dapat melihat nilai menggunakan telepon selular dan website.
\end{abstract}

Kata Kunci: WAP, telepon selular, website, php, mysql 
Jurnal Inkofar * Volume 1 No. 1 Juli 2019 * ISSN: 2615-3645 (Print) / 2581-2920 (Online)

Tersedia secara online di: http://www.politeknikmeta.ac.id/meta/ojs/

\section{PENDAHULUAN}

Teknologi internet saat ini tidak hanya dapat diakses menggunakan sebuah komputer, melainkan juga dapat menggunakan berbagai device seperti seperti telepon seluler atau smartphone dan sebagainya. Device tersebut dapat mengakses internet dengan teknologi wireless atau nirkabel sehingga dapat memberikan layanan yang cepat dan mudah kapanpun dan dimanapun. Para produsen telepon seluler memiliki suatu standar Wireless Application Protocol (WAP), sehingga dengan fasilitas WAP dapat mengakses internet. Seiring dengan perkembangan server web dan aplikasi pendukung lainnya, kini bagi institusi pendidikan semakin mudah dalam menyediakan server web, sehingga dapat mendukung untuk keperluan penyajian informasi. Server web dimanfaatkan untuk memberikan nilai tambah sebagai fasilitas untuk mahasiswa dalam mendapatkan informasi melalui halaman web yang dapat diakses melalui telepon selular atau website.

Politeknik Meta Industri Cikarang saat ini memerlukan suatu sistem yang dapat memberikan informasi nilai mahasiswa secara real time dan akurat yang dapat diakses oleh mahasiswa tanpa dibatasi oleh ruang dan waktu. Oleh karena itu diperlukan suatu sistem penyajian informasi yang sederhana yang memudahkan mahasiswa untuk mengetahui informasi nilai tanpa harus ke bagian pelayanan administrasi akademik.

Sistem tersebut memanfaatkan protocol WAP yang mampu menyajikan informasi dan dapat diakses melalui telepon selular yang memiliki fasilitas WAP browser dan GPRS (General Packet Radio Service).

\section{LANDASAN TEORI}

\subsection{Wireless Application Protocol (WAP)}

WAP merupakan suatu standar protokol, Dengan WAP seseorang yang mempunyai mobile devices dapat melakukan transaksi seperti berbelanja, operasi bank, dan pemesanan via internet.WAP adalah standar industri yang dikembangkan oleh sekelompok pabrik telekomunikasi (seperti Nokia, Ericsson, Motorola, dan lain-lain), operator telekomunikasi (seperti Deutche Telecom, France Telecom, AT\&T dan seterusnya),serta perusahaan software dan penyedia layanan (seperti Microsoft, IBM, Unwired Planet, dan lain sebagainya). (Janner Simarmata. 2006).

\subsection{WML (Wireless Markup Language)}

WML adalah wireless markup language berdasarkan Extensible Markup Language (XML).WML specification secara resmi awalnya telah dikembangkan dan dikelola oleh WAP Forum, sebuah pendiri consortium industry-wide yang didirikan oleh Nokia, Openwave, Motorola, dan Ericsson (Janner Simarmata, 2006). WML (Wireless Markup Language) adalah bahasa sekarang ini yang banyak digunakan untuk menulis isi pada telepon WAP.WML adalah sebuah bahasa markup. Maksudnya adalah halaman WML ditulis dan disimpan sebagai file-file teks dengan menggunakan 'tag-tag' seperti yang ditemukan pada HTML. (Janner Simarmata, 2006).

\subsection{MySQL}

Menurut Anhar (2010) MySQL adalah sebuah perangkat lunak sistem manajemen basis data SQL (Database Management System) atau DBMS dari sekian banyak DBMS, seperti Oracle, MS SQL, Postagre SQL, dan lain-lain. MySQL merupakan DBMS yang multithread, multi-user yang bersifat gratis (open source) dibawah lisensi GNU (General Public Licence) GPL. Karena sifat open source maka $M y S Q L$ dapat dipergunakan dan didistribusikan baik untuk kepentingan individu maupun corporate secara gratis, tanpa memerlukan lisensi dari pembuatnya. MySQL dapat dijalankan dalam berbagai platform sistem operasi antara lain Windows, Linuxs, Unix, Sun OS dan lain-lain.

2.4. UML

Menurut Dennis (2015) menyatakan UML (Unified Modeling Language) merupakan kosakata umum berbasis objek dan diagram teknik yang cukup efektif untuk memodelkan setiap proyek pengembangan sistem mulai tahap analisis sampai tahap desain dan implementasi.

\subsection{PHP}

PHP singkatan dari Hypertext Preprocessor yaitu bahasa pemrograman web server-side yang bersifat open source. PHP merupakan script yang terintegrasi dengan HTML dan berada pada server (serverside HTML embedded scripting). PHP adalah script yang digunakan untuk membuat halaman yang dinamis (up to date) (Anhar, 2010). 


\subsection{Penelitian Terdahulu}

Pada tahun 2015 penelitian yang dilakukan oleh Sutariyani dengan judul "Perancangan Sistem Informasi Kampus Berbasis WAP (Wireless Application Protocol) Studi Kasus STMIK AUB Surakarta. Pada penelitian ini menggunakan bahasa pemrograman WML (Wireless Markup Language) dan PHP dengan basisdata MySQL. Basis data dapat ditambah, diedit dan dihapus melalui website oleh web admin. Pengujian sistem dengan menggunakan emulator WAP M3Gate sebagai pengganti telepon selular. Pengguna dapat mengakses informasi kampus dengan menggunakan telepon selular dengan teknologi WAP.

Penelitian selanjutnya yang dilakukan oleh Adi Fajaryanto Cobantoro (2016) dengan judul "Perancangan Wireless Application Protokol dan Web Sistem Informasi Studi Kasus SMU N IV Madiun". Pada penelitian ini menggunakan PHP dan WML, aplikasi untuk admin diakses menggunakan website. Sedangkan untuk pengguna dapat diakses menggunakan telepon selular berbasis WAP serta menggunakan website. Informasi yang dihasilkan untuk kebutuhan karyawan, siswa dan masyarakat.

\section{METODE PENELITIAN}

\subsection{Alur penelitian}

Pada tahap ini dalam menyelesaikan penelitian dimulai dari pengumpulan data, perancangan sistem, pembangunan sistem kemudian dilakukan pengujian terhadap sistem berbasis WAP dan Web. Setelah proses pengujian berhasil dilanjutkan dengan implementasi sistem, jika terdapat kesalahan maka akan dilakukan perbaikan pada proses-proses sebelumnya.

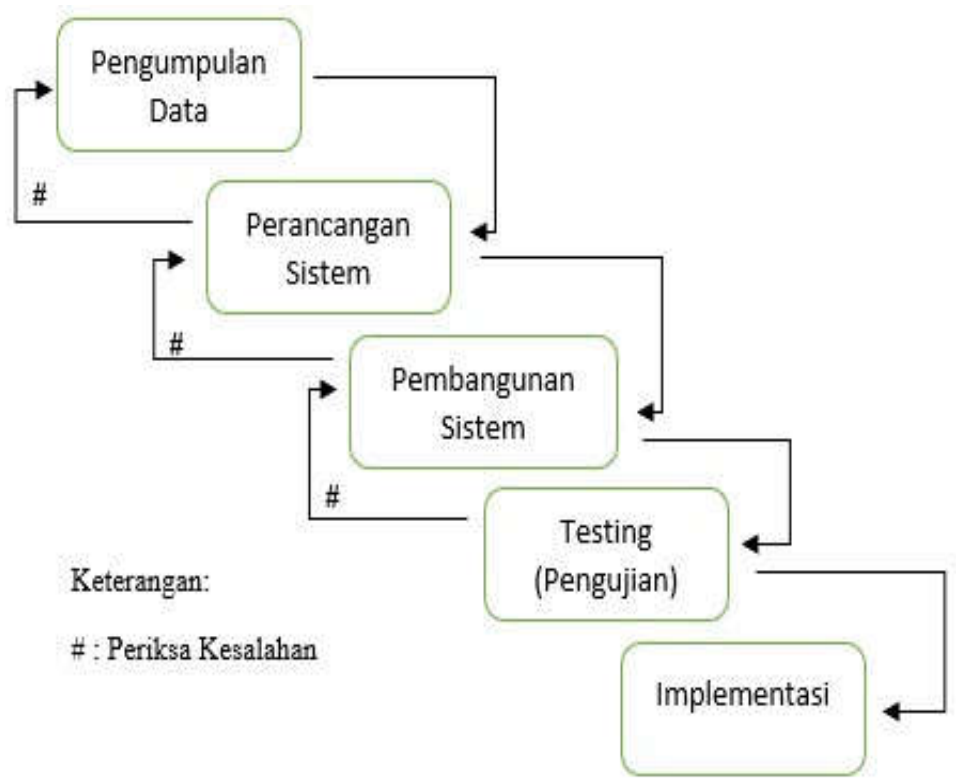

Gambar 1. Alur Penelitian

\subsection{Pengumpulan Data}

Data yang mendukung dalam penelitian ini meliputi data primer dan data sekunder. Data primer yaitu data yang diperoleh langsung dari bagian Pelayanan Biro Administrasi Akademik (BAAK). Pada tahap ini didapatkan data sampel berupa data mahasiswa angkatan 2018 semester 2 Prodi Teknik Komputer sebanyak 10 mahasiswa, data dosen Teknik Komputer sebanyak 15, data matakuliah, data nilai UTS, UAS dan KAT (Kuis Absen Tugas). Data sekunder yaitu data yang diperoleh dengan membaca artikel-artikel, literatur-literatur atau buku-buku yang berhubungan dengan penelitian. 


\subsubsection{Perancangan sistem}

a. Diagram alur perancangan sistem

Berikut adalah diagram alur dalam perancangan sistem dari sisi admin dan mahasiswa.

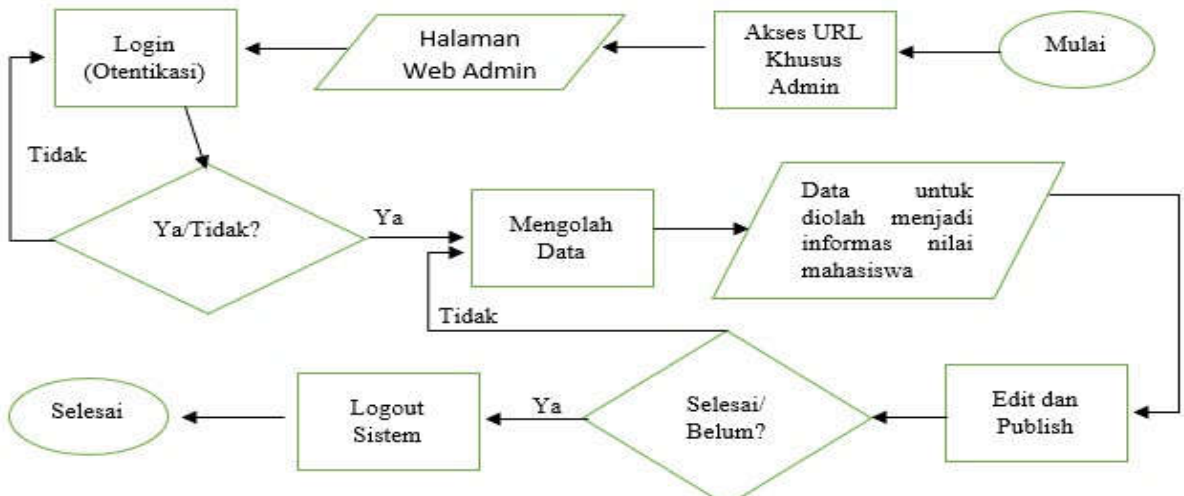

Gambar 2. Alur Sistem Sisi Admin Web

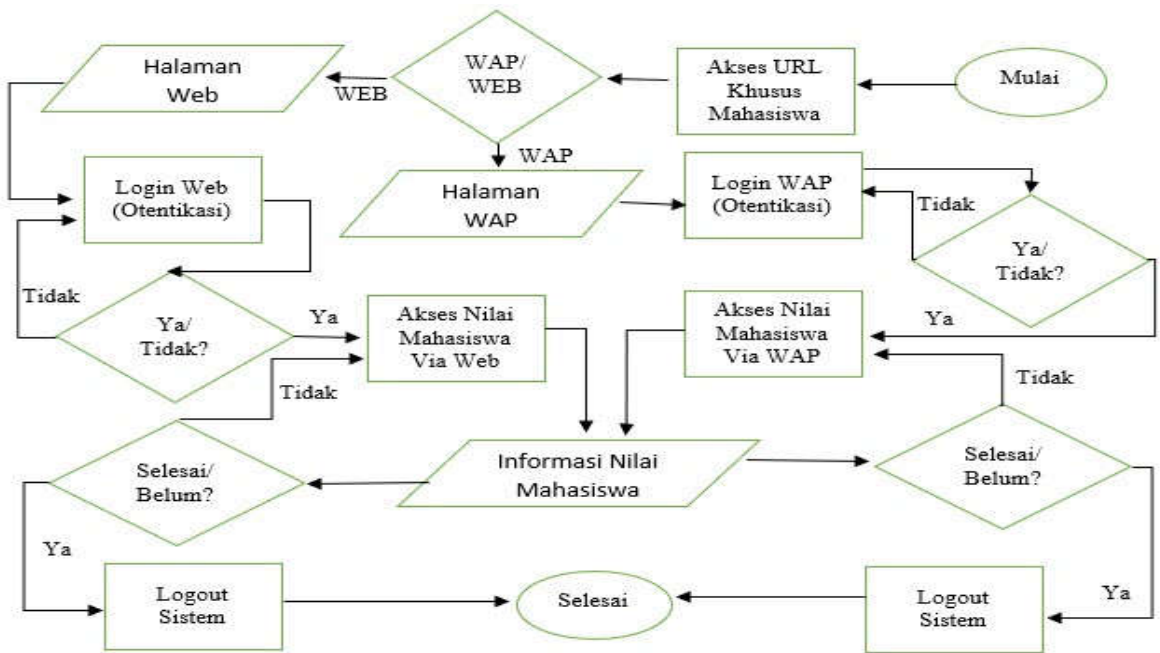

Gambar 3. Alur Sistem Sisi Mahasiswa ( WAP dan Web)

b. $\quad$ ERD (Entity Relationship Diagram)

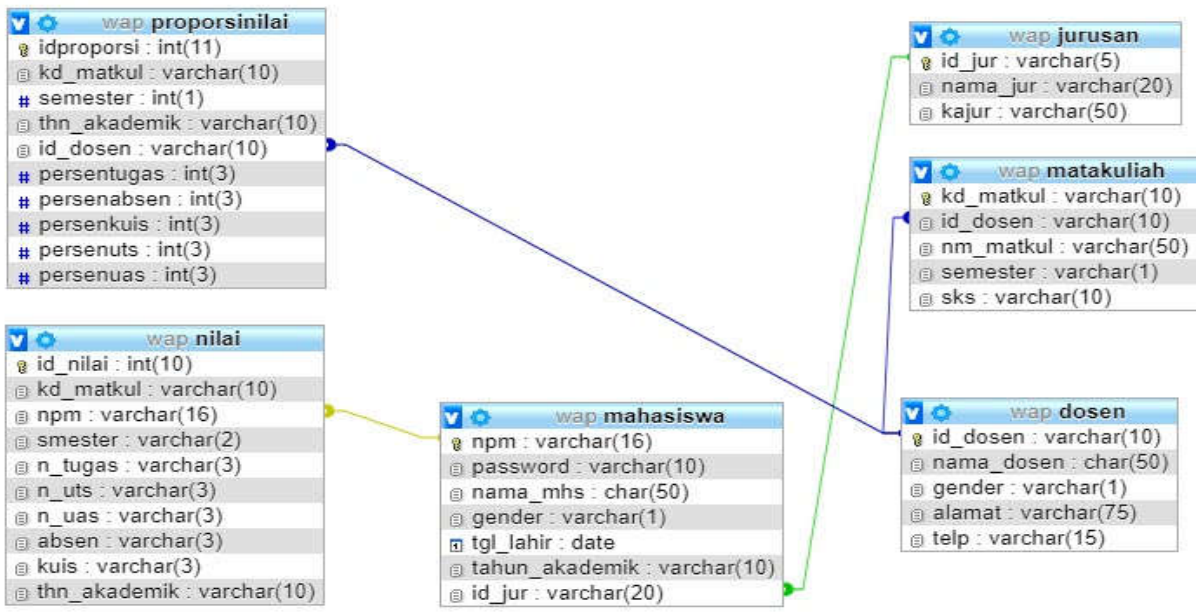

Gambar 4. Relasi antar table 


\section{HASIL DAN PEMBAHASAN}

\subsection{Implementasi Dan Uji Perangkat Lunak}

Untuk sistem yang berbasis teknologi $W A P$ dibangun menggunakan bahasa pemrograman $P H P$ dan $W M L$. Untuk sistem yang berbasis website dibangun menggunakan bahasa pemrograman $P H P$ dengan desain tampilan yang membutuhkan kemampuan grafis yang memadai. Sistem berbasis teknologi $W A P$ dan website menggunakan basis data yang sama yaitu MYSQL. Sistem ini diimplementasikan pada server cloud yang sudah terintegrasi antara server web, $P H P$ dan MYSQL. Pada tahap pengujian, sistem dengan teknologi WAP diakses menggunakan telepon selular. Untuk tipe telepon selular dengan spesifikasi rendah dapat mengaksesnya menggunakan url khusus untuk sistem berteknologi $W A P$, sedangkan telepon selular dengan spesifikasi tinggi atau smartphone dapat mengakses url sistem WAP menggunakan browser versi tertentu seperti opera mini. Untuk sistem berbasis website nya dapat diakses dengan resolusi dan tampilan terbaik menggunakan browser versi terkini baik melalui smartphone maupun komputer. Untuk sistem teknologi WAP hanya menampilkan informasi dalam bentuk teks atau tulisan saja, sedangkan untuk sistem teknologi website menampilkan informasi dalam bentuk teks, warna dan gambar. Sistem dengan teknologi website dapat memberikan tampilan terbaik apabila diakses dengan device baik telepon selular yang spesifikasi smartphone maupun komputer.

\subsubsection{Halaman Login Mahasiswa dengan (WAP)}

Halaman ini adalah halaman index atau awal yang tampil ketika pengguna menggunakan telepon selular dalam mengakses informasi nilai.

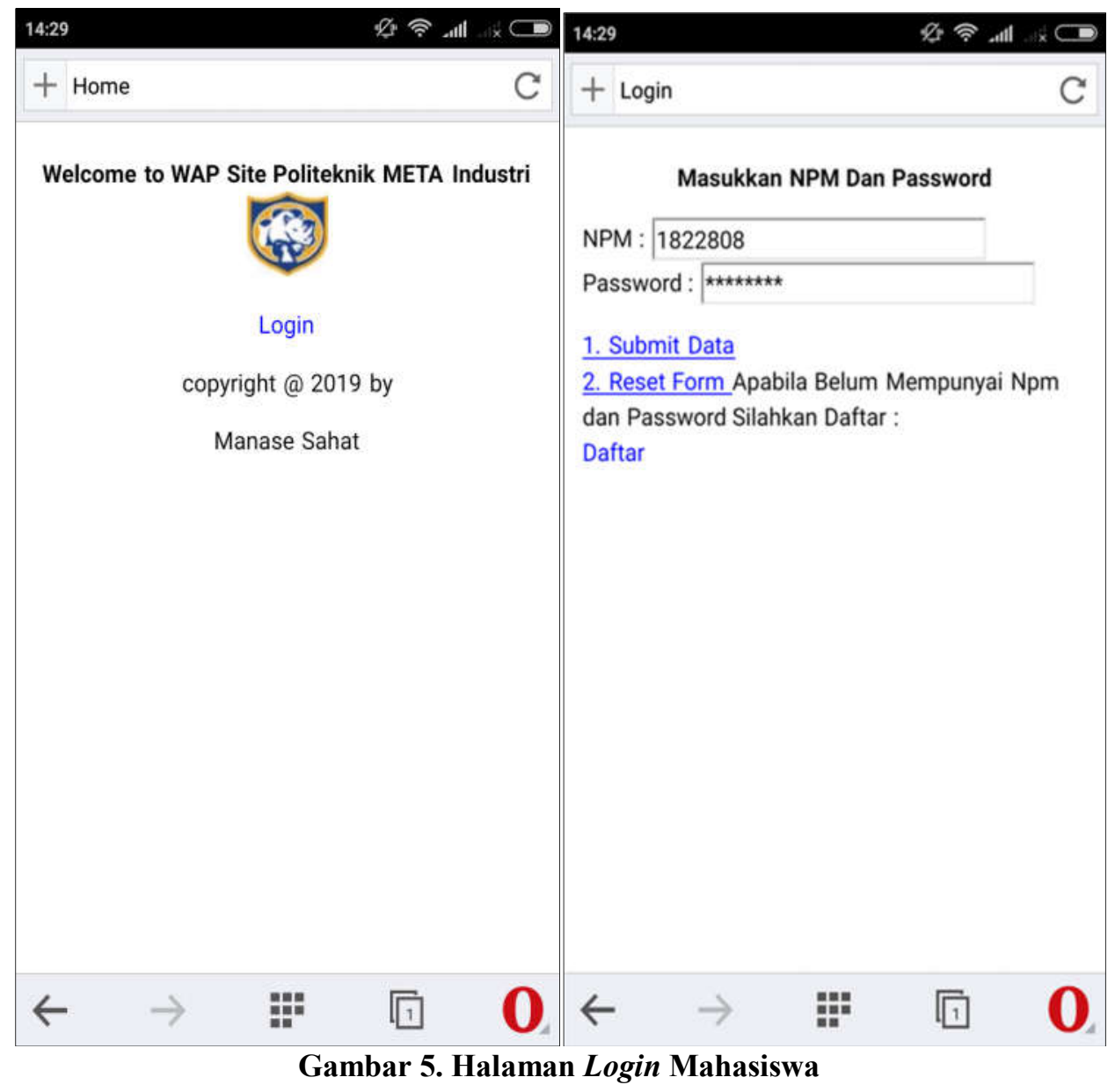




\subsubsection{Halaman Data Pribadi Mahasiswa}

Halaman ini akan menampilkan informasi data pribadi mahasiswa setelah berhasil melakukan login.

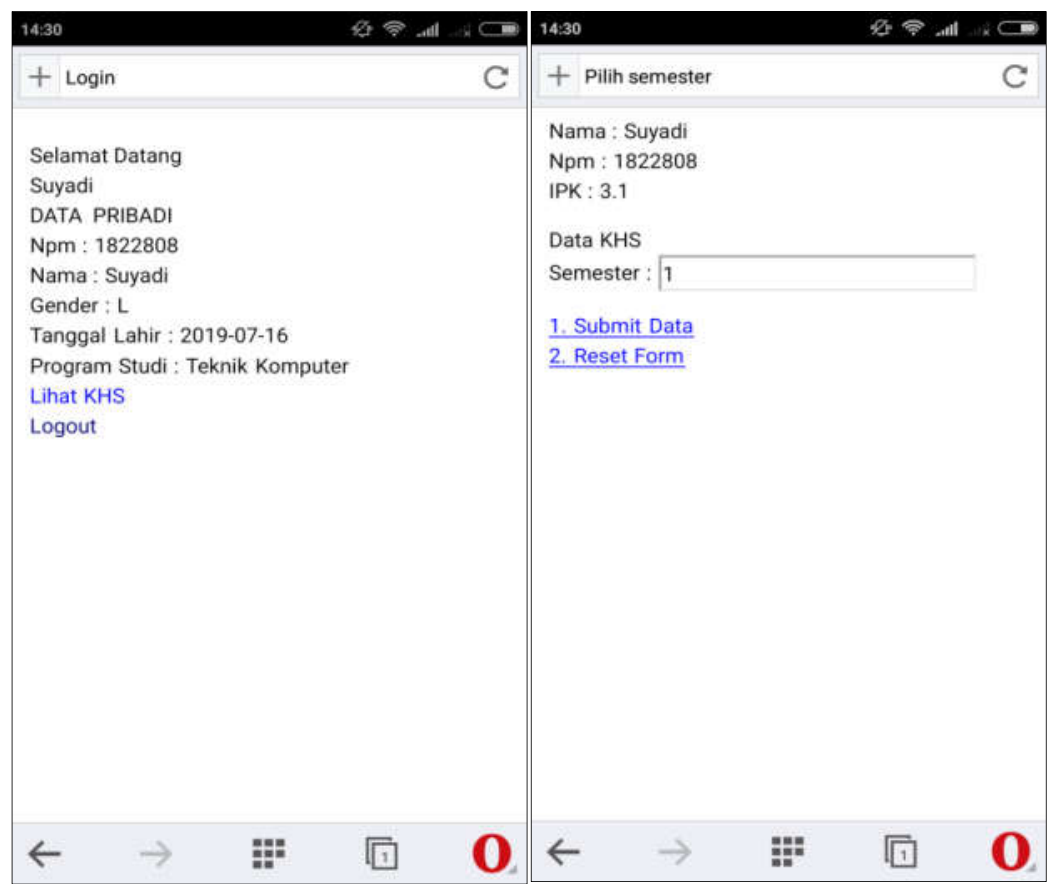

Gambar 6. Halaman Data Pribadi Mahasiswa

\subsubsection{Halaman Nilai KHS}

Setelah mahasiswa memilih semester yang mereka inginkan, maka sistem akan memunculkan hasil nilai khs sesuai dengan semester.

\begin{tabular}{l}
\hline 14:30 \\
\hline Daftar Nilai KHS \\
\hline Nama : Suyadi \\
Npm : 1822808 \\
Semester : 1 \\
Tahun Akademik : $2018 / 2019$ \\
IP Semester : 2.75 \\
\hline 1.Agama Islam \\
Nilai : A \\
SKS : 2 \\
Bobot : 4 \\
Mutu : 8 \\
\hline 2.Dasar Pemrograman \\
Nilai : A \\
SKS : 3 \\
Bobot : 4 \\
Mutu : 20 \\
\hline 3.Aljabar Linear \\
Nilai : C+ \\
SKS : 2 \\
Bobot : 2.5 \\
Mutu : 25 \\
\hline$\leftarrow$ \\
\hline
\end{tabular}

\begin{tabular}{l} 
14:30 \\
\hline 4.Fisika Mekanika \\
Nilai : : \\
SKS : 2 \\
Bobot : 2 \\
Mutu : 29 \\
\hline 5. Pengantar Teknologi Informasi \\
Nilai : B+ \\
SKS : 3 \\
Bobot : 3.5 \\
Mutu : 39.5 \\
\hline 6. Bahasa Indonesia \\
Nilai : A \\
SKS : 2 \\
Bobot : 4 \\
Mutu : 47.5 \\
\hline 7.Pendidikan Pancasila dan Kewarganegaraan \\
Nilai : B+ \\
SKS : 2 \\
Bobot : 3.5 \\
Mutu : 54.5 \\
\hline Detail \\
Kembali \\
$\leftarrow$ \\
\hline
\end{tabular}

Gambar 7. Halaman Hasil KHS 
4.1.4. Halaman Detail Nilai

Setelah mahasiswa melihat hasil nilai khs, mahasiswa juga dapat melihat nilai secara detail dengan memilih menu detail.

\begin{tabular}{|c|c|}
\hline 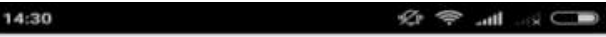 & 14:31 \\
\hline+ wap.adambhuana.web.id/detailkhs.php?npm $=C$ & Tugas : 80 \\
\hline Daftar Detail Nilai : & UAS: 80 \\
\hline 1. Agama Islam & $\begin{array}{l}\text { Absen : } 95 \\
\text { Posen : Febie Elfaladona MKom }\end{array}$ \\
\hline Jumlah Sks : 2 & \\
\hline Kuis : 87 & 6. Bahasa Indonesia \\
\hline Tugas : 78 & Jumlah Sks: 2 \\
\hline UTS : 90 & Kuis : 80 \\
\hline UAS : 89 & Tugas : 80 \\
\hline Absen : 95 & UTS : 85 \\
\hline Dosen : Supriyatin & UAS : 85 \\
\hline $\begin{array}{l}\text { 2.Dasar Pemrograman } \\
\text { Jumlah Sks: } 3\end{array}$ & $\begin{array}{l}\text { Absen : } 95 \\
\text { Dosen : Ianatul Munhimah, S.PdI }\end{array}$ \\
\hline Kuis : 87 & 7.Pendidikan Pancasila dan Kewarganegaraan \\
\hline Tugas : 78 & Jumlah Sks: 2 \\
\hline UTS : 89 & Kuis : 80 \\
\hline UAS : 75 & Tugas : 80 \\
\hline Absen : 95 & UTS : 75 \\
\hline Dosen : Manase Sahat, M.Kom & UAS : 70 \\
\hline 3. Aljabar Linear & $\begin{array}{l}\text { Absen : } 95 \\
\text { Dosen : Benni Sinaga, S.E, M.Si. }\end{array}$ \\
\hline Kuis : 80 & Kembali \\
\hline Tugas : 75 & Logout \\
\hline$\leftarrow \quad \rightarrow \quad \mathbb{Z}$ & 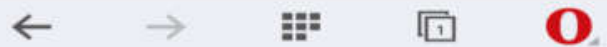 \\
\hline
\end{tabular}

Gambar 8. Halaman Hasil Detail Nilai

\subsubsection{Halaman Login Admin dan Mahasiswa dengan web}

Halaman ini diakses menggunakan browser selain opera mini atau opera versi terkini. Pengguna dengan perangkat mobile spesifikasi tinggi atau terkini akan diarahkan ke halaman login berikut.

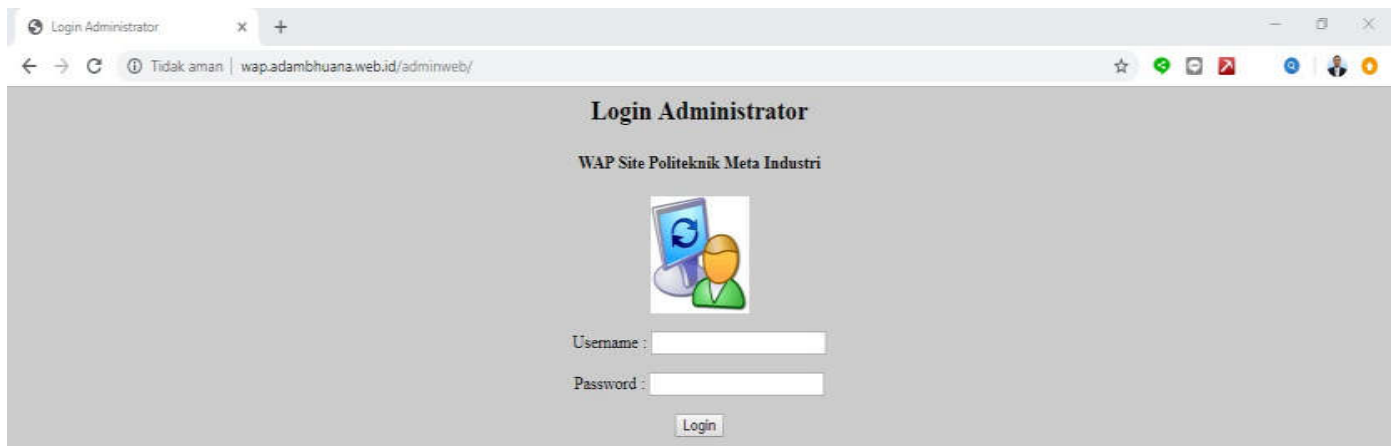

Gambar 9. Halaman Login Admin

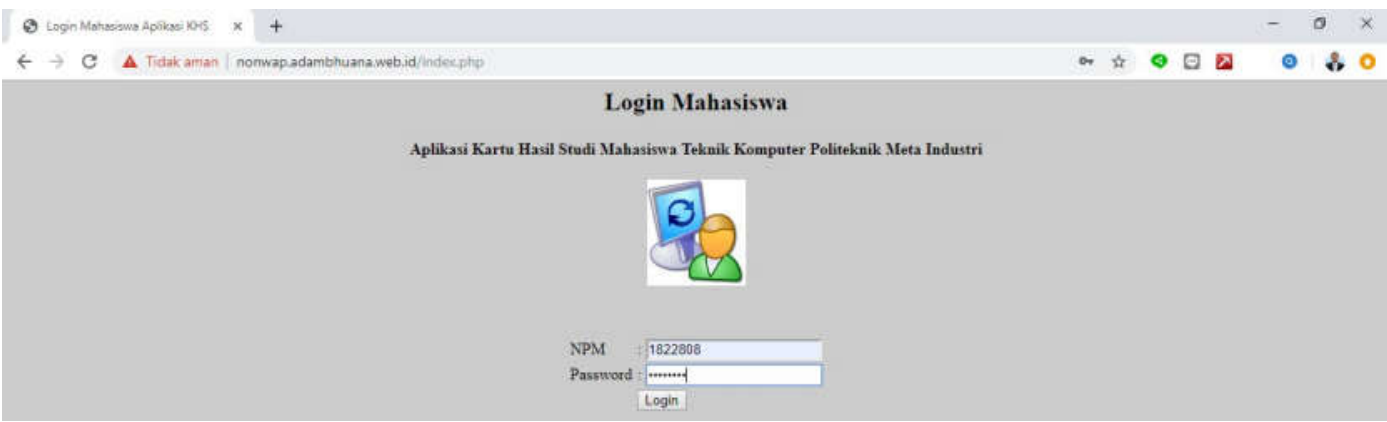

Gambar 10. Halaman Login Mahasiswa 


\subsubsection{Halaman Menu Utama Admin dan Mahasiswa dengan web}

Ketika pengguna yang telah diberikan otorisasi admin atau mahasiswa dapat masuk ke sistem dengan sukses, maka akan terbuka halaman utama seperti yang tampil pada gambar berikut.

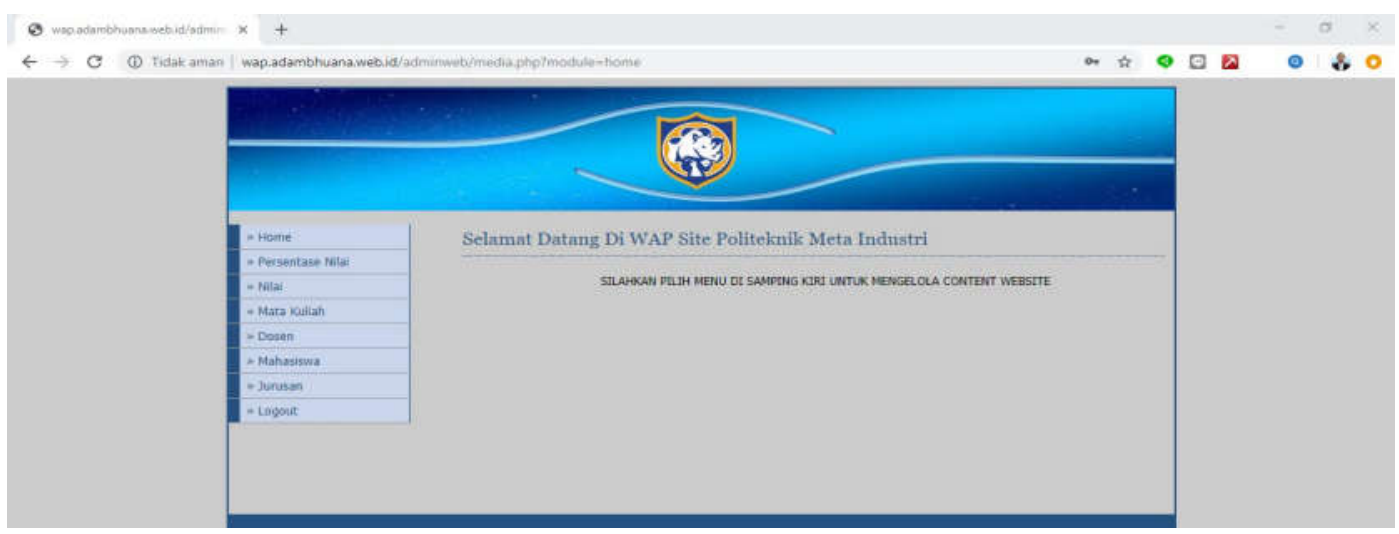

Gambar 11. Halaman Menu Utama Admin

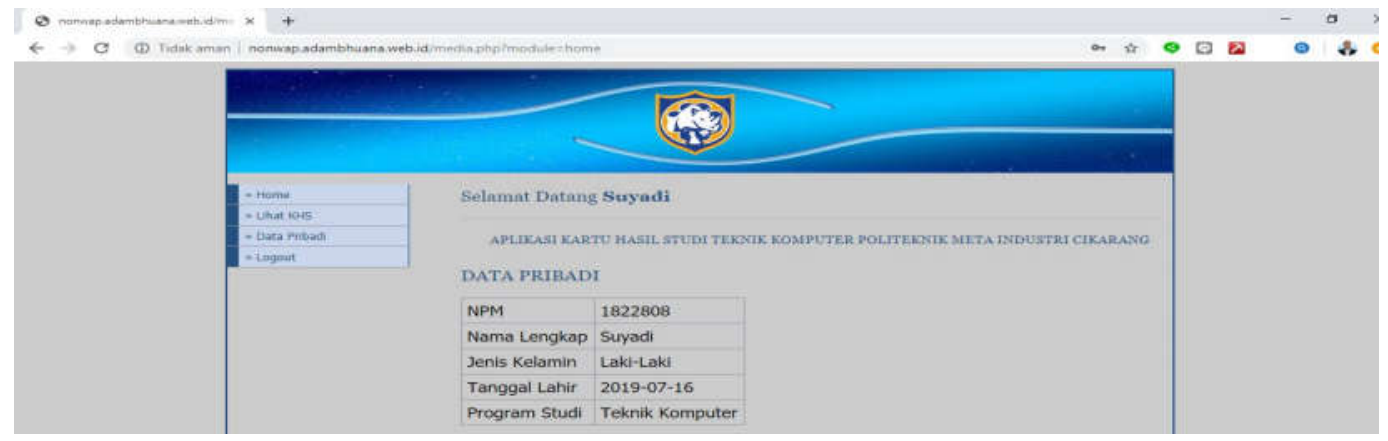

Gambar 12. Halaman Menu Utama Mahasiswa

\subsubsection{Halaman Menu Lihat KHS}

Halaman menu lihat KHS ini menampilkan nilai keseluruhan atau Index Prestasi Kumulatif (IPK) mahasiswa.

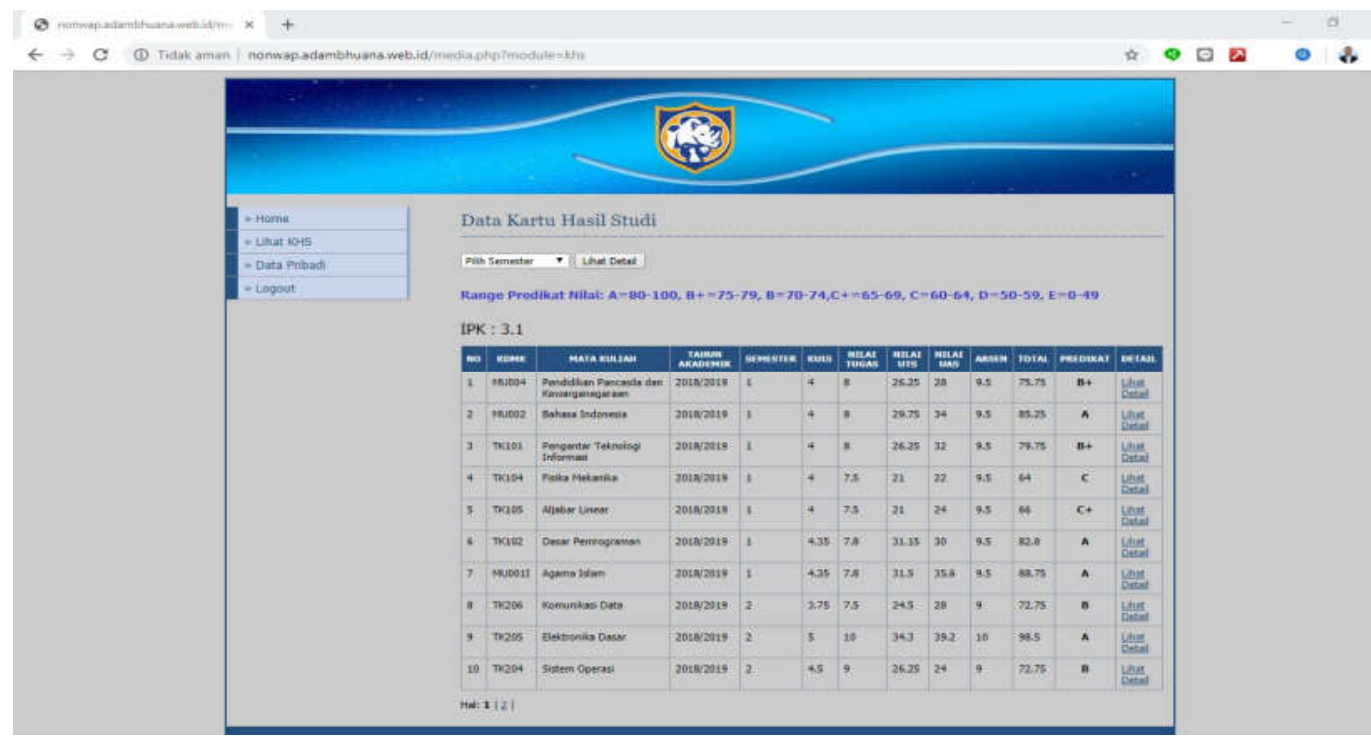

Gambar 13. Halaman Menu Lihat KHS 


\subsubsection{Halaman Menu Detail Nilai Per Mata Kuliah}

Halaman menu detail nilai per mata kuliah ini akan tampil apabila pengguna mengakses tautan (link) 'Lihat Detail'yang terdapat pada setiap baris data nilai mata kuliahnya.

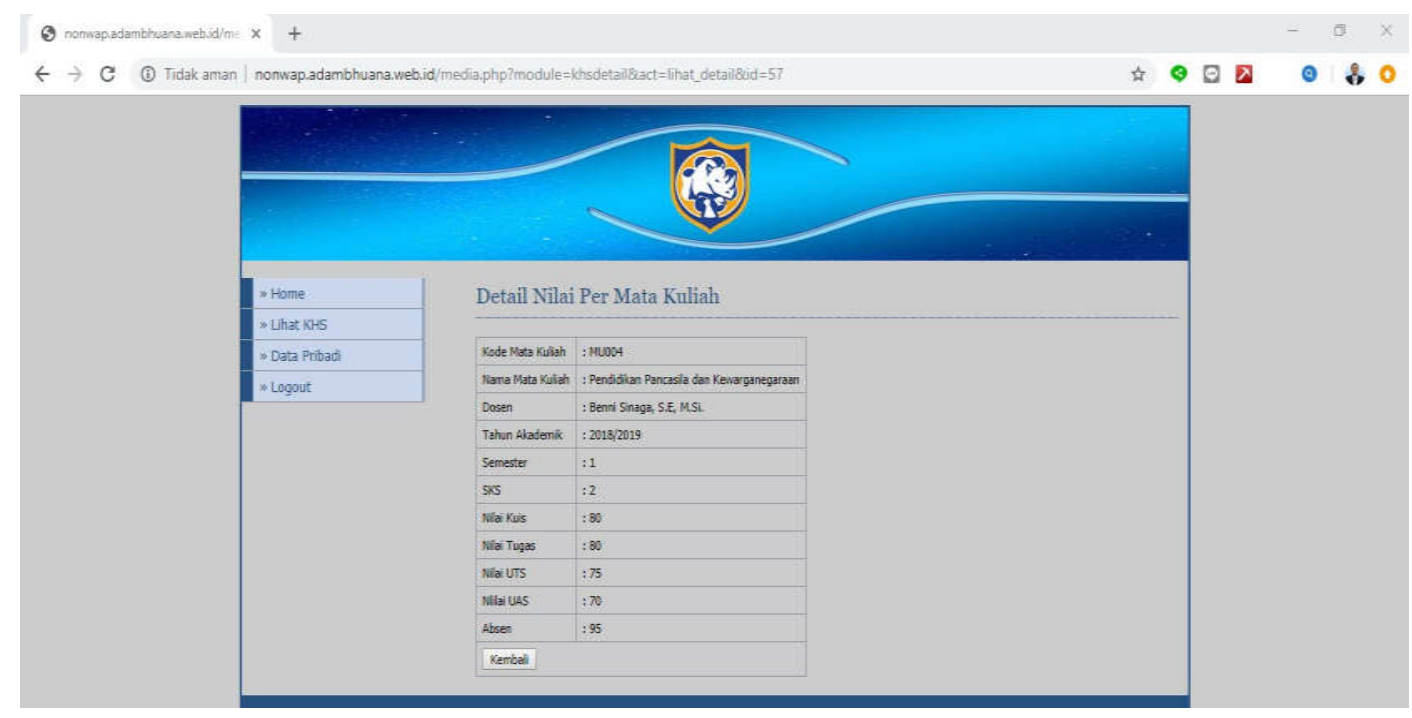

Gambar 14. Halaman Menu Detail Nilai

\section{KESIMPULAN DAN SARAN}

\subsection{Kesimpulan}

Pada penelitian ini mulai dari tahap perancangan sistem, pengembangan sistem, hingga tahap implementasi penulis menarik suatu kesimpulan sebagai berikut :

1. Sistem informasi nilai berbasis $W A P$ dan $W e b$ ini memberikan kemudahan bagi mahasiswa di Politeknik Meta Industri Cikarang khususnya program studi Teknik Komputer untuk melihat nilai kapan pun dan dimanapun.

2. Sistem informasi nilai berbasis teknologi $W A P / W E B$ memberikan kemudahan bagi mahasiswa agar dapat diakses baik menggunakan telepon selular (spesifikasi rendah dan smartphone) maupun dengan komputer.

\subsection{Saran}

Dari aplikasi yang telah dibuat penulis juga ingin memberikan beberapa saran diantaranya adalah :

1. Tampilan sistem informasi nilai berbasis $W e b$ belum dapat menyesuaikan tampilannya sesuai dengan ukuran telepon selular, hanya dapat menunjukkan tampilan terbaik pada komputer dengan resolusi tinggi.

2. Pada sistem informasi nilai berteknologi $W A P$ belum ada menu untuk mengubah kata sandi mahasiswa, sehingga mahasiswa harus bertanya ke bagian akademik untuk kata sandi.

3. Pada sisi admin sistem informasi nilai ini belum dibuatkan akun untuk para dosennya sehingga pengolahan nilai bisa lebih efektif dan efisien. Saat ini pengolahan nilai masih menggunakan akun admin.

\section{DAFTAR PUSTAKA}

Anhar. 2010. PHP dan MySQL Secara Otodidak. Media Kita. Jakarta Selatan.

Cobantoro, A.F 2016. "Perancangan Wireless Application Protokol dan Web Sistem Informasi Studi Kasus SMU N IV Madiun". Jurnal Ilmiah NERO, Vol 2, No 2.

Dennis, Alan, Barbara Haley Wixom, dan David Tegarden. 2015. System Analysis Design an ObjectOriented Approach with UML Fifth Edition. New Jersey: WILEY.

Hartawan, A 2013." Implementasi Wireless Application Protocol (WAP) Untuk Layanan Pengisian KRS di Politama Surakarta”. Jrnal Nasional Teknik Elektro dan Teknologi Informasi- JNTETI, Vol 2, No 4. 
Jurnal Inkofar * Volume 1 No. 1 Juli 2019 * ISSN: 2615-3645 (Print) / 2581-2920 (Online)

Tersedia secara online di: http://www.politeknikmeta.ac.id/meta/ojs/

Kuway, S.M 2015. "Penerapan Teknologi Wireless Application Protocol Untuk Pemesanan Tiket Taxi Berbasis Mobile". Seminar Nasional Informatika 2015.

Simarmata, Janner. 2006. Aplikasi Mobile Commerce Menggunakan PHP dan MySQL. Andi Yogyakarta.

Simarmata, Janner. 2006, Pemrograman WAP denganmenggunakan WML. Andi Yogyakarta. Yogyakarta

Sutabri, Tata 2010. Konsep Sistem Informasi, Andi Offset Yogyakarta. Yogyakarta.

Sutariyani, 2015." Perancangan Sistem Informasi Kampus berbasis WAP (Wireless Application Protocol)". Indonesian Journal on Networking and Security-IJNS, Vol 4, No 1. 